\title{
No Relation of Plasma Morphine Level to the Severity of Naloxone- Induced Withdrawal in Acute Morphine-Dependent Rats
}

\author{
Shiroh Kishioka, Norihiro Inoue, Shigeru Nishida, Yuko Fukunaga and Hiroyuki Yamamoto \\ Department of Pharmacology, Wakayama Medical College, 9-Bancho 27, Wakayama 640, Japan \\ Received May 26, 1995 Accepted August 1, 1995
}

\begin{abstract}
Plasma morphine concentration and naloxone-precipitated withdrawal body weight loss and plasma corticosterone (PCS) increase were determined at 12,18 and $24 \mathrm{hr}$ after i.v. infusion of morphine at a constant rate of $10 \mathrm{mg} / \mathrm{kg} / \mathrm{hr}$ for $4 \mathrm{hr}$ in Sprague-Dawley rats. Plasma morphine concentration declined $98.0 \%$ within $12 \mathrm{hr}$ and further declined $58.8 \%$ during $12-24 \mathrm{hr}$ after morphine infusion. There was a significant difference between plasma morphine concentrations at 12 and $24 \mathrm{hr}$ after the morphine infusion. Naloxone $(0.5$ and $2.0 \mathrm{mg} / \mathrm{kg}$ )-precipitated withdrawal, but not spontaneous withdrawal, was elicited at 12-24 hr after the morphine infusion, and the severity of withdrawal precipitated by $2.0 \mathrm{mg} / \mathrm{kg}$ naloxone was the same at $12-24 \mathrm{hr}$ after the morphine infusion. Furthermore, there was no significant correlation between plasma morphine concentration and body weight loss or PCS increase. The results suggest that a constant degree of morphine dependence is sustained during 12-24 hr after the morphine infusion and the severity of naloxone-precipitated withdrawal is not related to the plasma morphine concentration at the time of naloxone injection, that is, the rate of morphine removal from its receptor sites.
\end{abstract}

Keywords: Intravenous morphine infusion, Plasma morphine concentration, Naloxone-withdrawal, Body weight loss, Plasma corticosterone increase

Physical dependence on morphine is evidenced by the withdrawal syndromes that follow the discontinuation of morphine exposure (spontaneous withdrawal) or the treatment with an opioid antagonist (antagonist-precipitated withdrawal) in laboratory animals (1); the severity of the syndrome is thought to reflect the degree of physical dependence. Morphine withdrawal must be initiated by the removal of morphine from opioid receptors.

Yoburn et al. (2) demonstrated that the time course of morphine withdrawal was inversely related to the elimination rate of plasma morphine and that body weight loss correlated with plasma morphine levels just before withdrawal in rats implanted with morphine pellets. Furthermore, Domino et al. (3) showed that the negative relationship between the plasma morphine concentration and the severity of withdrawal could be quantified in a simple logarithmic equation in morphine-dependent monkeys. The plasma morphine level has been thought to correlate with the morphine concentration in the vicinity of their binding sites and the amount of morphine bound to opioid receptors. These findings, then, suggest that the severity of morphine withdrawal is related to the rate of removal of morphine from the opioid receptors in spon- taneous morphine withdrawal.

Opioid antagonist, naloxone-precipitated morphine withdrawal is thought to be initiated through an immediate replacement of morphine by naloxone at their binding sites. Thus the rate of morphine removal from the receptor sites after sufficient naloxone may depend on the morphine concentration in the receptor sites at the time of naloxone injection. If the severity of naloxone-precipitated withdrawal is related to the rate of morphine removal, a correlation of plasma morphine concentration with the naloxone-precipitated withdrawal would be expected.

On the other hand, it has been reported that naloxoneprecipitated body weight loss (4) and plasma corticosterone (PCS) increase $(5,6)$ are quantitative indicators of morphine withdrawal, and we have shown that the intensities of both signs were related to the dose of naloxone and the duration of morphine treatment, indicating that the magnitude of the body weight loss and the PCS increase reflect the degree of morphine dependence (7).

In the present study, we assessed the naloxone-precipitated withdrawal body weight loss and PCS increase and the plasma morphine concentration at different times after morphine infusion, and we clarified the relationship 
between the intensity of the naloxone-precipitated withdrawal and the plasma morphine concentration at the time of naloxone injection in rats infused intravenously with morphine.

\section{MATERIALS AND METHODS}

Male Sprague-Dawley rats (Nihon Clea Co., Tokyo) weighing $250-300 \mathrm{~g}$ were used. They were housed in twos in suspended wire cages in an animal room with controlled temperature $\left(23-24^{\circ} \mathrm{C}\right)$, humidity $(60 \%)$ and lighting (7:00-19:00). Food (MF; Oriental Yeast Co., Osaka) and water were available ad libitum.

A cannula was implanted in the right external jugular vein under pentobarbital anesthesia $(50 \mathrm{mg} / \mathrm{kg}$, i.p.) according to Upton (8). After cannulation, the rats were housed individually and allowed a recovery period of 3 days, after which they were made morphine dependent by i.v. infusion of drug via the cannula at a constant rate of $10 \mathrm{mg} / \mathrm{kg} / \mathrm{hr}$ for $4 \mathrm{hr}$ in a volume of $1 \mathrm{ml} / \mathrm{hr} /$ rat (Roller pump; Furue Science, Tokyo). Naloxone (2.0 or 0.5 $\mathrm{mg} / \mathrm{kg}$, s.c.) was challenged at 12,18 and $24 \mathrm{hr}$ or 12 and $24 \mathrm{hr}$ after the termination of morphine infusion, and naloxone-induced body weight loss and PCS increase were assessed.

Body weight change $(\%)$ was calculated as follows: [(body weight at $60 \mathrm{~min}$ before naloxone-body weight at $120 \mathrm{~min}$ after naloxone)/body weight at $60 \mathrm{~min}$ before naloxone] $\times 100$.

To estimate the change of PCS level, serial blood samples $(0.4 \mathrm{ml})$ were obtained via the cannula at $0,30,60,90$ and $120 \mathrm{~min}$ after naloxone in freely moving animals. Immediately after each blood sampling, an equal volume of saline was transferred to the jugular vein through the cannula. The time of i.v. infusion of morphine was adjusted in order to collect blood samples between 9:30 and 12:00 to avoid circadian variation in circulating PCS. The collected blood samples were centrifuged at $2000 \times \mathrm{g}$ for $15 \mathrm{~min}$ at $4^{\circ} \mathrm{C}$, and the plasma was stored at $-20^{\circ} \mathrm{C}$ until assayed. The PCS was estimated fluorometrically according to the method of Zenker and Bernstein (9).

For the determination of the plasma morphine concentration, blood samples (over $2 \mathrm{ml}$ ) were obtained immediately after the last sampling for the PCS assay, that is, $2 \mathrm{hr}$ after naloxone injection under the pentobarbital anesthesia. Plasma morphine content was determined by the HPLC-ECD method (10) as follows: The mixture of plasma samples $(1 \mathrm{ml})$ and $1 \mathrm{ml}$ of $40 \%$ of $\mathrm{K}_{2} \mathrm{HPO}_{4}$ solution was shaken with $5 \mathrm{ml}$ of ethylacetate for $20 \mathrm{~min}$ and then centrifuged at $2000 \times g$ for $5 \mathrm{~min}$ at $4^{\circ} \mathrm{C}$. The organic layer was collected, and the aqueous layer was re-extracted with $5 \mathrm{ml}$ of ethylacetate. Then, the morphine in the two $5-\mathrm{ml}$ fractions of organic layer were successively ex- tracted with $1 \mathrm{ml}$ of $1 \mathrm{M}$ acetic acid, and a $0.9-\mathrm{ml}$ portion of the aqueous layer was lyophilized. The sample was dissolved in $200 \mu \mathrm{l}$ of $0.01 \mathrm{~N} \mathrm{HCl}$, and $20 \mu l$ was analyzed by the HPLC-ECD system. The conditions of the HPLC-ECD system were as follows: column, Eicompak MA-ODS (Eicom, Kyoto); mobile phase, $0.1 \mathrm{M}$ citricacetate buffer ( $\mathrm{pH} 3.9) /$ methanol (82/18) containing 3 $\mathrm{mg} /$ liter of EDTA and $150 \mathrm{mg} /$ liter of sodium octane sulfonate; flow rate, $1 \mathrm{ml} / \mathrm{min}$; detector, ECD-100 (Eicom) $750 \mathrm{mV} \mathrm{Ag} / \mathrm{AgCl}$; temperature, $25^{\circ} \mathrm{C}$. In this assay, a level of $4 \mathrm{ng} / \mathrm{ml}$ plasma was the lower limit of detection.

Morphine (morphine hydrochloride; Takeda Chem. Industries, Ltd., Osaka) and naloxone (naloxone hydrochloride; Endo Labo., Inc., Garden City, NY, USA) were dissolved in saline, being freshly prepared before

\section{A. Naloxone, $2.0 \mathrm{mg} / \mathrm{kg}$}

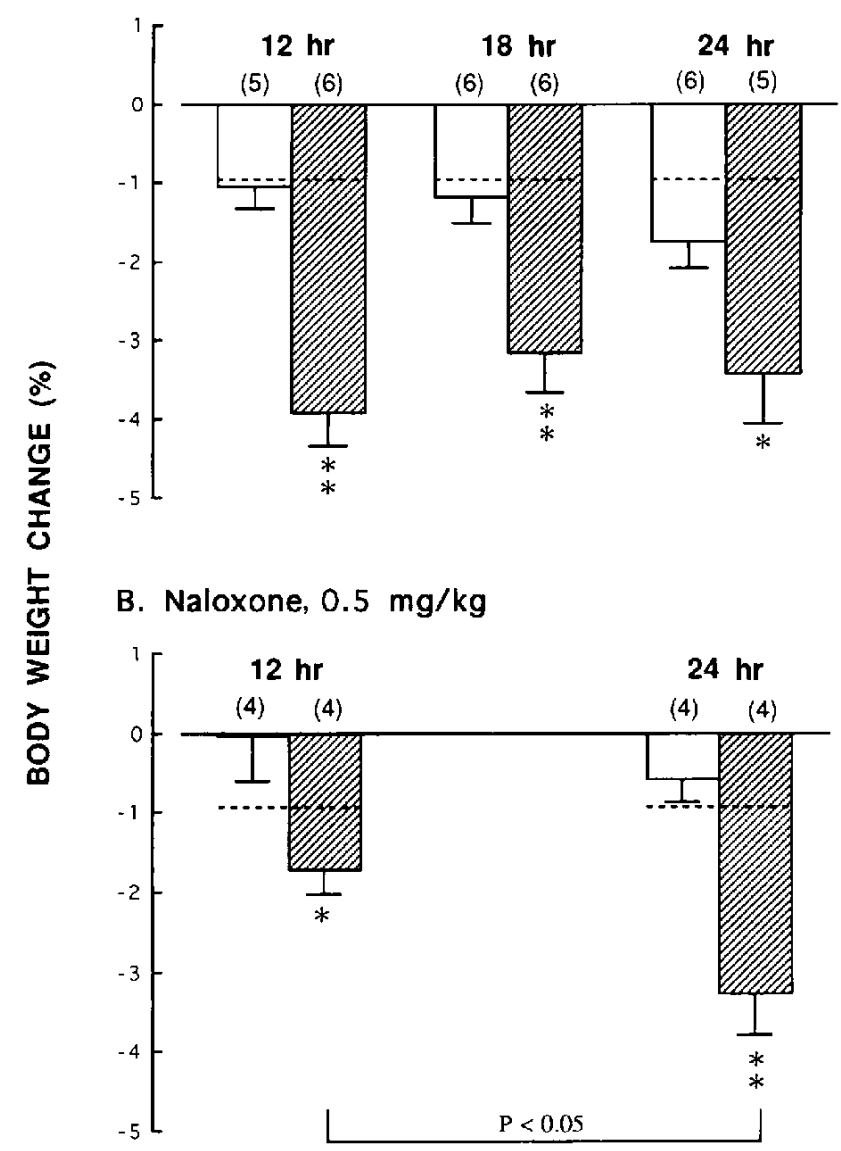

Fig. 1. Body weight loss induced by naloxone $(2.0$ and $0.5 \mathrm{mg} / \mathrm{kg}$, s.c.) at 12-24 hr after termination of 4-hr morphine infusion. Each column represents body weight changes $(\%)$ during $3 \mathrm{hr}$ (between 1 $\mathrm{hr}$ before and $2 \mathrm{hr}$ after saline or naloxone). Dashed lines indicate the mean body weight changes in naive rats. Open and hatched columns represent body weight changes after saline and naloxone treatment, respectively. The numbers in parentheses are the number of rats. Each value represents the mean; vertical bars indicate the S.E.M. Difference from each saline treatment, ${ }^{*} \mathrm{P}<0.05,{ }^{* *} \mathrm{P}<0.01$. 
use. Other chemicals were purchased from the following sources: sodium pentobarbital (Nembutal; Dinabot, North Chicago, IL, USA); sodium acetate, citric acid monohydrate, EDTA-2Na (special grade; Katayama Chemicals, Osaka); sodium octane sulfonate (HPLC grade; Nacalai Tesque, Kyoto) and methanol (HPLC grade; Kanto Chemicals, Tokyo).

Values are expressed as means \pm S.E.M. Linear regression analysis was used for the evaluation of relationships between plasma morphine concentration and withdrawal signs. Data were analyzed by a one way analysis of variance (ANOVA) followed by the Newman-Keuls test for multiple comparison; unpaired Student's $t$-test was used for comparison between groups (11).

\section{RESULTS}

Body weight loss induced by naloxone
Body weight increases of $2.45 \pm 0.55 \% \quad(n=11)$, $2.58 \pm 0.64 \%(n=12)$ and $2.38 \pm 0.44 \%(n=11)$ were observed during 11,17 and $23 \mathrm{hr}$ after 4-hr morphine infusion, respectively. Progressive body weight loss was not elicited by the discontinuance of morphine infusion; i.e., spontaneous withdrawal was not elicited within $23 \mathrm{hr}$ after the termination of morphine infusion.

In naive rats, a body weight decrease of $0.98 \pm 0.38 \%$ $(n=5)$ was observed during $3 \mathrm{hr}$, and the degree of body weight loss in morphine-infused and saline-treated rats was the same as that in naive rats. These results indicate further that spontaneous withdrawal was not elicited during 12-24 hr after the termination of morphine infusion.

Significant body weight loss was induced by naloxone $(0.5$ and $2.0 \mathrm{mg} / \mathrm{kg}$ ) injected at 12,18 or $24 \mathrm{hr}$ after morphine infusion (Fig. 1). There was no difference between the magnitude of body weight loss induced by a large dose
A. Naloxone, $2.0 \mathrm{mg} / \mathrm{kg}$

$12 \mathrm{hr}$

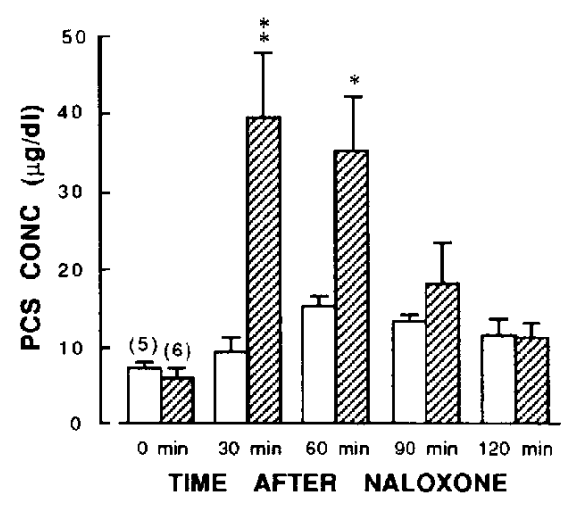

B. Naloxone, $0.5 \mathrm{mg} / \mathrm{kg}$

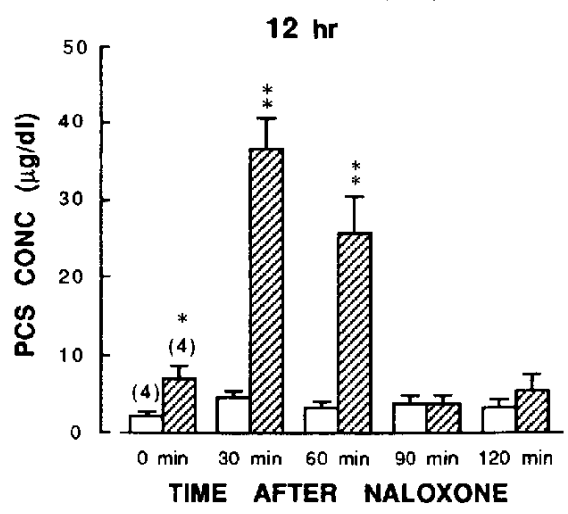

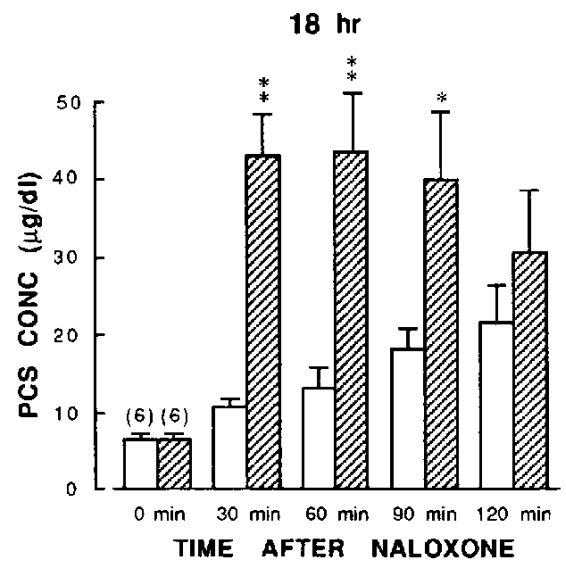

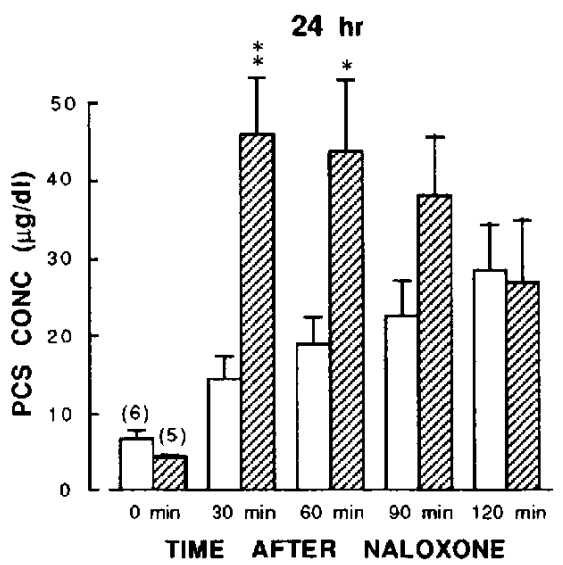

TIME AFTER NALOXONE

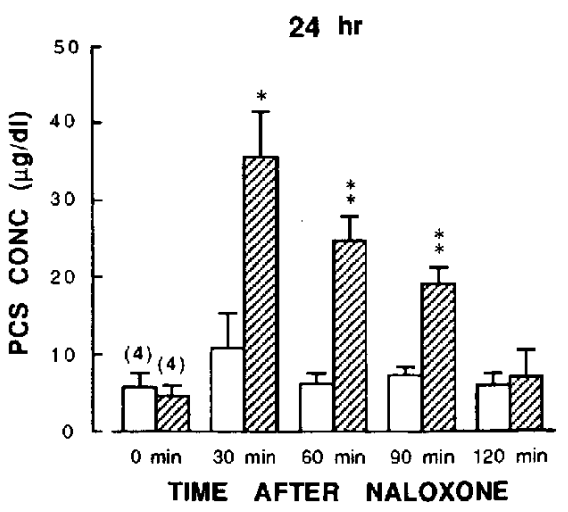

Fig. 2. Time course of plasma corticosterone increase induced by naloxone ( 2.0 and $0.5 \mathrm{mg} / \mathrm{kg}, \mathrm{s.c}$.) at $12-24 \mathrm{hr}$ after termination of 4-hr morphine infusion. Open and hatched columns represent plasma corticosterone levels after saline and naloxone treatments, respectively. PCS, plasma corticosterone; CONC, concentration. The numbers in parentheses are the number of rats. Each value represents the mean; vertical bars indicate the S.E.M. Difference from each saline treatment, ${ }^{*} \mathrm{P}<0.05$, ${ }^{* *} \mathrm{P}<0.01$. 
of naloxone $(2.0 \mathrm{mg} / \mathrm{kg})$ injected at 12,18 or $24 \mathrm{hr}$ after morphine infusion (Fig. 1A), while the body weight loss induced by a small dose of naloxone $(0.5 \mathrm{mg} / \mathrm{kg})$ at $12 \mathrm{hr}$ was less than that at $24 \mathrm{hr}$ after morphine infusion (Fig. 1B).

\section{Plasma corticosterone increase induced by naloxone}

PCS levels before saline or naloxone at 12,18 and $24 \mathrm{hr}$ after 4-hr morphine infusion were $5.7 \pm 0.7(\mu \mathrm{g} / \mathrm{dl}$, $\mathrm{n}=19), 6.3 \pm 0.6(\mu \mathrm{g} / \mathrm{dl}, \mathrm{n}=12)$ and $5.4 \pm 0.6(\mu \mathrm{g} / \mathrm{dl}$, $\mathrm{n}=19$ ), respectively (Fig. 2). These PCS levels were the same as that in morphine-naive rats (7), indicating that spontaneous withdrawal was not elicited during 12-24 hr after the termination of morphine infusion.

A significant increase in PCS was evoked by naloxone $(0.5$ and $2.0 \mathrm{mg} / \mathrm{kg}$ ) injected at 12,18 or $24 \mathrm{hr}$ after $4-\mathrm{hr}$ morphine infusion with the maximum naloxone-induced PCS increase at $30 \mathrm{~min}$, followed by a decline and disappearance within $120 \mathrm{~min}$ after naloxone (Fig. 2). The PCS levels $30 \mathrm{~min}$ after a large dose of naloxone $(2.0 \mathrm{mg} / \mathrm{kg})$ were $39.5 \pm 8.1(\mu \mathrm{g} / \mathrm{dl}, \mathrm{n}=6), 43.1 \pm 5.2(\mu \mathrm{g} / \mathrm{dl}, \mathrm{n}=6)$ and $46.1 \pm 7.3(\mu \mathrm{g} / \mathrm{dl}, \mathrm{n}=5)$ at 12,18 and $24 \mathrm{hr}$ after morphine infusion, respectively; and there was no significant difference among these levels (Fig. 2A).

The PCS levels $30 \mathrm{~min}$ after a small dose of naloxone $(0.5 \mathrm{mg} / \mathrm{kg})$ were $36.0 \pm 4.1(\mu \mathrm{g} / \mathrm{dl}, \mathrm{n}=4)$ and $35.0 \pm 5.8$ $(\mu \mathrm{g} / \mathrm{dl}, \mathrm{n}=4)$ at 12 and $24 \mathrm{hr}$ after morphine infusion, respectively; and there was no significant difference between these levels (Fig. 2B).
Plasma morphine concentration after morphine infusion

During i.v. infusion of morphine at a constant rate of $10 \mathrm{mg} / \mathrm{kg} / \mathrm{hr}$, the plasma morphine concentration gradually increased and reached the maximum level at $60 \mathrm{~min}$ after the start of infusion, being maintained at a steady state level until the termination of morphine infusion (data not shown).

The time course of decline of plasma morphine concentration after morphine infusion is presented in Fig. 3. The morphine concentration at the end of morphine infusion was $1.922 \pm 0.185 \mu \mathrm{g} / \mathrm{ml}(\mathbf{n}=34)$. After that, the plasma morphine level decreased sharply to $0.038 \mu \mathrm{g} / \mathrm{ml}$ (mean of saline- and naloxone-treated group); i.e., a $98.0 \%$ decline, during the initial $12 \mathrm{hr}$ after infusion. From $12 \mathrm{hr}$ onward, plasma morphine concentration decreased slowly and was $0.016 \mu \mathrm{g} / \mathrm{ml}$ (mean of salineand naloxone-treated group) at $24 \mathrm{hr}$, resulting in a $58.8 \%$ decline during the later $12 \mathrm{hr}$. There was a significant difference between plasma morphine concentrations at 12 and $24 \mathrm{hr}$ after infusion; i.e., decrease of plasma morphine concentration was also significant during $12-24 \mathrm{hr}$ after morphine infusion. In the saline- and naloxone-treated rats, plasma morphine concentrations were the same at 12,18 and $24 \mathrm{hr}$ after morphine infusion, indicating that naloxone did not affect the plasma morphine level.

Correlation of body weight loss and plasma corticosterone level to plasma morphine concentration

The scatterplot of body weight loss or increased PCS

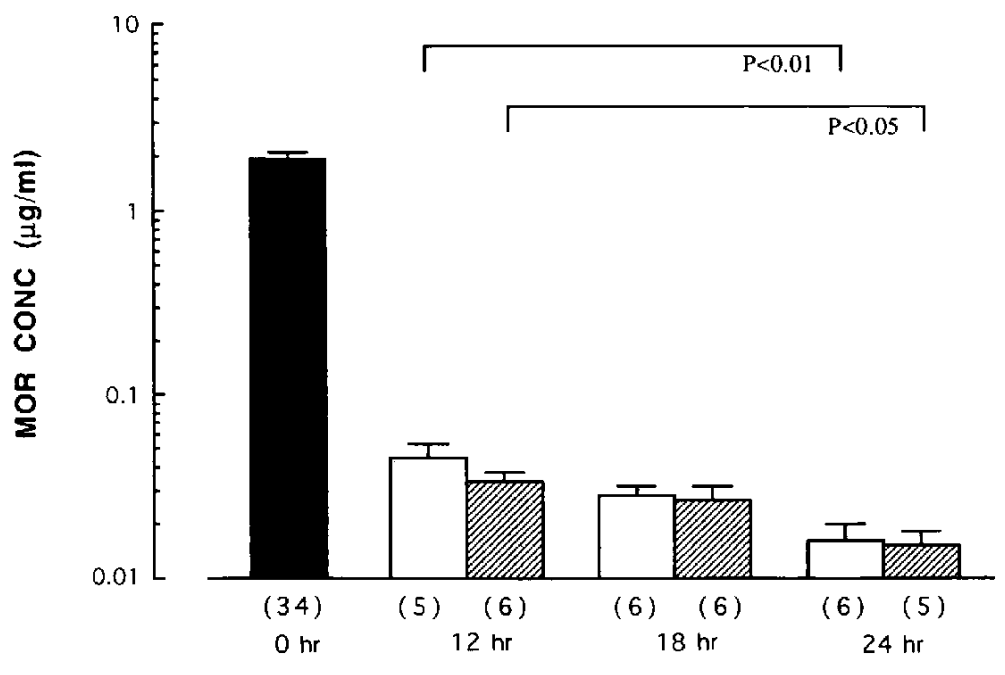

TIME AFTER THE TERMINATION OF MOR INFUSION

Fig. 3. Plasma morphine concentrations after termination of 4-hr morphine infusion. Saline or naloxone was challenged at $\mathbf{1 2 \text { , }}$ 18 and $24 \mathrm{hr}$ after the termination of morphine infusion. Closed column represents morphine concentration just after termination of morphine infusion. Open (saline treatment) and hatched (naloxone treatment) columns indicate morphine concentration at $2 \mathrm{hr}$ after saline and naloxone $(2.0 \mathrm{mg} / \mathrm{kg}, \mathrm{s.c}$.) treatments, respectively. MOR, morphine; CONC, concentration. The numbers in parentheses are the number of rats. Each value represents the mean; vertical bars indicate the S.E.M. 

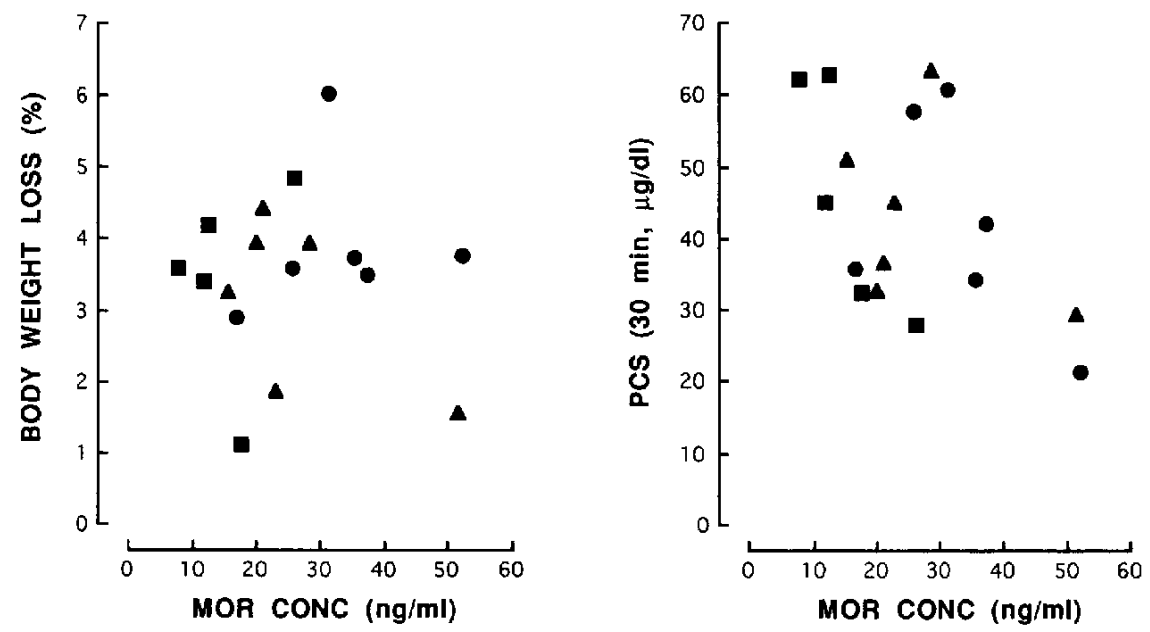

Fig. 4. Scattergram of plasma morphine concentration vs body weight loss or vs increased plasma corticosterone levels ( $30 \mathrm{~min}$ after naloxone) induced by a large dose of naloxone $(2.0 \mathrm{mg} / \mathrm{kg}$, s.c.). Closed circle, closed triangle and closed square indicate the data of rats injected with naloxone at 12,18 and $24 \mathrm{hr}$ after termination of morphine infusion, respectively. Data are from Figs. 1 and 2. MOR, morphine; CONC, concentration; PCS, plasma corticosterone.

levels ( $30 \mathrm{~min}$ after naloxone) induced by $2.0 \mathrm{mg} / \mathrm{kg}$ of naloxone against plasma morphine concentration at naloxone challenge is shown in Fig. 4. The data at 12, 18 and $24 \mathrm{hr}$ after termination of morphine infusion were included in this analysis. Neither the body weight loss nor the PCS levels induced by naloxone was correlated with the plasma morphine concentration at naloxone challenge.

\section{DISCUSSION}

Rats were rendered morphine dependent by intravenous infusion of morphine at a constant rate of 10 $\mathrm{mg} / \mathrm{kg} / \mathrm{hr}$ for $4 \mathrm{hr}$, and naloxone-precipitated withdrawal signs and plasma morphine concentration were estimated 12,18 and $24 \mathrm{hr}$ after morphine infusion to investigate the relationship between the severity of naloxone-precipitated withdrawal and the plasma morphine concentration at the time of naloxone injection.

In the present study, the steady state level of plasma morphine was $1.922 \mu \mathrm{g} / \mathrm{ml}$ during infusion and declined to about $0.038 \mu \mathrm{g} / \mathrm{ml}$ at $12 \mathrm{hr}$ after the conclusion of morphine infusion (Fig. 3). In spite of a remarkable decline of plasma morphine concentration within the initial $12 \mathrm{hr}(98.0 \%$ decline from $1.922 \mu \mathrm{g} / \mathrm{ml})$, neither body weight loss nor PCS increase, both reliable indices of abstinence (7), was induced.

Yoburn et al. (2) demonstrated an $85 \%$ decline of plasma morphine concentration from the steady-state level of $0.210 \mu \mathrm{g} / \mathrm{ml}$ within $12 \mathrm{hr}$ after removal of morphine pellets before the onset of spontaneous withdrawal body weight loss in rats implanted with two $75 \mathrm{mg}$ morphine pellets for $72 \mathrm{hr}$; plasma morphine concentration, at which significant withdrawal body weight loss was observed, was calculated as $0.210 \mu \mathrm{g} / \mathrm{ml} \times 0.15=0.0315$ $\mu \mathrm{g} / \mathrm{ml}$. In our study, the plasma morphine concentration at $12 \mathrm{hr}$ after morphine infusion (Fig. 3) was similarly as low as that at $\mathbf{1} \mathbf{h r}$ after removal of morphine pellets as calculated above, and the rate of decline of plasma morphine concentration after morphine infusion (from 1.922 $\mu \mathrm{g} / \mathrm{ml}$ to $0.038 \mu \mathrm{g} / \mathrm{ml}$ per $12 \mathrm{hr}$ ) was rather higher than that after pellet removal (from $0.210 \mu \mathrm{g} / \mathrm{ml}$ to 0.032 $\mu \mathrm{g} / \mathrm{ml}$ per $12 \mathrm{hr}$ ), although spontaneous withdrawal body weight loss was not induced within $12 \mathrm{hr}$ after the morphine infusion. On the other hand, naloxone induced body weight loss at $12 \mathrm{hr}$ after morphine infusion (Fig. 1).

Naloxone-precipitated withdrawal has been reported in mice (12), rats (5) and humans (13) treated with a single dose of morphine and in dogs (14) infused with morphine for $7 \mathrm{hr}$, although spontaneous withdrawal signs were not observed in these morphine-dependent models. The morphine dependence induced by implantation of morphine pellets can be revealed by naloxone-precipitated withdrawal (4) or spontaneous withdrawal (removal of morphine pellets) (2). Thus the degree of morphine dependence conferred in the present study may have been lower than that in the morphine pellet implanted rats, and in spontaneous withdrawal, it is suggested that both the minimum plasma concentration of morphine below which withdrawal signs can be induced and the rate of decline of plasma morphine which may be involved in the initiation of withdrawal vary with the degree of morphine dependence.

It is well-known that the onset and peak of naloxone- 
precipitated withdrawal occur earlier than spontaneous withdrawal. Naloxone-precipitated withdrawal is dosedependent $(5,7)$ and is antagonized by pretreatment with morphine (15). Thus naloxone-precipitated withdrawal may be initiated by the rapid replacement of morphine by naloxone at their binding sites. The amount of morphine replaced by naloxone may be so small that the plasma morphine concentration was not affected by naloxone (Fig. 3).

The plasma morphine concentration declined significantly during $12-24 \mathrm{hr}$ after morphine infusion, i.e., plasma morphine concentration at $12 \mathrm{hr}$ was 2.4 times higher than that at $24 \mathrm{hr}$ after morphine infusion (Fig. 3). Naloxone-induced body weight loss was dose-dependent at $12 \mathrm{hr}$ after morphine infusion and $0.5 \mathrm{mg} / \mathrm{kg}$ naloxone-induced body weight loss at $24 \mathrm{hr}$ was greater than that at $12 \mathrm{hr}$ after morphine infusion (Fig. 1), whereas there was no difference in the body weight loss induced by $2.0 \mathrm{mg} / \mathrm{kg}$ naloxone injection at 12,18 or $24 \mathrm{hr}$ after morphine infusion (Fig. 1). These results suggest that i) the severity of naloxone-precipitated withdrawal was affected by morphine concentration in the vicinity of their binding sites, ii) $2.0 \mathrm{mg} / \mathrm{kg}$ of naloxone sufficed for maximum replacement of morphine at the binding sites under this experimental condition and iii) the degree of morphine dependence was constant during $24 \mathrm{hr}$ after morphine infusion.

Increase in PCS was induced by both 0.5 and 2.0 $\mathrm{mg} / \mathrm{kg}$ of naloxone (Fig. 2). This was consistent with the report (5) that PCS increase was induced by naloxone even after a single dose of morphine. Also, there was no difference in PCS levels at 30 min after naloxone injected 12,18 or $24 \mathrm{hr}$ after 4 -hr morphine infusion. All of these results suggest that a constant degree of morphine dependence was sustained until $24 \mathrm{hr}$ after ending morphine infusion. The duration of morphine dependence in the present study is consistent with the finding (13) that the magnitude of naloxone-precipitated abstinence at $6 \mathrm{hr}$ was similar to that at $24 \mathrm{hr}$ after a single dose of morphine in humans.

The replacement of morphine by naloxone at its receptor sites may be rapid. It is, then, presumed that the receptor milieu morphine concentration at the time of a sufficient dose of naloxone reflects the rate of morphine removal from its receptor sites. Since the morphine concentration at its receptor sites may be in a dynamic equilibrium with the plasma morphine concentration, investigation of the correlation of plasma morphine concentration to severity of naloxone-precipitated withdrawal would be a good model for studying the relation of the rate of morphine removal at the receptor sites to the severity of naloxone-precipitated withdrawal. As mentioned above, a significant decline of plasma morphine concentration was observed during $12-24 \mathrm{hr}$ after morphine infusion (Fig. 3), but there was no difference in the severity of naloxone-induced body weight loss or PCS increase at 12, 18 and $24 \mathrm{hr}$ after morphine infusion (Figs. 1 and 2), and no significant correlation of the plasma morphine concentration to the severity of the naloxoneinduced body weight loss and PCS increase was observed (Fig. 4). If the plasma morphine level at $12-24 \mathrm{hr}$ after morphine infusion correlates with the morphine concentration in the vicinity of their binding site and the amount of morphine bound to opioid receptors, these results suggest that the severity of naloxone-precipitated withdrawal is not related to the rate of morphine removal from its receptor sites.

In summary, spontaneous withdrawal was not elicited in rats infused with morphine $(10 \mathrm{mg} / \mathrm{kg} / \mathrm{hr}$ for $4 \mathrm{hr})$ even by a change of plasma morphine concentration that was comparable to the change observed before the onset of withdrawal body weight loss in two $75 \mathrm{mg}$ morphine pellet-implanted rats. Body weight loss and PCS increase were induced by naloxone and the severity of the morphine withdrawal induced by naloxone $(2.0 \mathrm{mg} / \mathrm{kg})$ at 12,18 and $24 \mathrm{hr}$ after morphine infusion was the same. Moreover, there was no correlation between the plasma morphine concentration and the severity of naloxoneprecipitated withdrawal. These results suggest that the degree of morphine dependence was constant during $12-24 \mathrm{hr}$ after morphine infusion, and the severity of naloxone-precipitated withdrawal is not related to the rate of morphine removal from its receptor sites.

\section{REFERENCES}

1 Jaffe JH: Drug addiction and drug abuse. In The Pharmacological Basis of Therapeutics, 8th edition, Edited by Gilman AG, Rall TW, Nies AS and Taylor P, pp 522-573, Pergamon Press, New York (1990)

2 Yoburn BC, Chen J, Huang $\mathrm{T}$ and Inturrisi CE: Pharmacokinetics and pharmacodynamics of subcutaneous morphine pellets in the rat. J Pharmacol Exp Ther 235, 282-286 (1985)

3 Domino EF, Dahlstrom BE, Domino LE and Domino SE: Relation of plasma morphine concentrations to severity of abrupt withdrawal in morphine-dependent monkeys. J Pharmacol Exp Ther 243, $138-143$ (1987)

4 Wei E, Loh HH and Way EL: Quantitative aspects of precipitated abstinence in morphine-dependent rats. J Pharmacol Exp Ther 184, 398-403 (1973)

5 Eisenberg RM: Further studies on the acute dependence produced by morphine in opiate naive rats. Life Sci $\mathbf{3 1}$, 1531 - 1540 (1982)

6 Yamamoto H, Mikita S, Yano I, Masuda Y and Murano T: Studies on the physical dependence liability of analgesics. 2nd report: Relationship between transformation of intramitochondrial structures in adrenocortical cells and corticosterone biosynthesis in morphine addicted rats. Jpn J Pharmacol 23, $217-225$ (1973) 
7 Kishioka S, Nishida S, Fukunaga Y and Yamamoto H: Quantitative properties of plasma corticosterone elevation induced by naloxone-precipitated withdrawal in morphine-dependent rats. Jpn J Pharmacol 66, 257-263 (1994)

8 Upton RA: Simple and reliable method for serial sampling of blood from rats. J Pharm Sci 64, 112-114 (1975)

9 Zenker $\mathrm{N}$ and Bernstein DE: The estimation of small amount of corticosterone in rat plasma. J Biol Chem 231, 695-701 (1958)

10 Miyamoto Y, Morita N, Kitabata Y, Yamanishi T, Kishioka S, Ozaki $\mathrm{M}$ and Yamamoto $\mathrm{H}$ : Antinociceptive synergism between supraspinal and spinal sites after subcutaneous morphine evidenced by CNS morphine content. Brain Res 552, 136-140 (1991)

11 Tallarida RJ and Murray RB: Manual of Pharmacologic Calculations with Computer Programs, 2nd edition, Springer-
Verlag, New York (1987)

12 Yano I and Takemori AE: Inhibition by naloxone of tolerance and dependence in mice treated acutely and chronically with morphine. Res Commun Chem Pathol Pharmacol 16, 721-734 (1977)

13 Heishman SJ, Stitzer ML, Bigelow GE and Liebson IA: Acute opioid physical dependence in humans: Effect of naloxone at 6 and 24 hours postmorphine. Pharmacol Biochem Behav 36, $393-399$ (1990)

14 Martin WR and Eades CG: A comparison between acute and chronic physical dependence in the chronic spinal dog. J Pharmacol Exp Ther 146, 385-394 (1964)

15 Suzuki T, Fukagawa Y, Yoshii T, Yanaura S and Katz JL: Modification of the effects of naloxone in morphine-dependent mice. Life Sci 45, $1237-1246$ (1989) 